\title{
The Paradox of Managing for Outcomes
}

\author{
Karen Lewis
}

\section{Introduction}

Government departments are required to consider and report on the linkages between departmental outputs and the government's intended outcomes (Steering Group Managing for Outcomes Roll-Out 2003/04, 2002). But are the objectives of 'managing for outcomes' (MFO) being achieved? While, as Ryan (2006) noted, it may be too early to conclusively answer questions around MFO, it is possible to reflect on the practice in light of the evidence available in departmental statements of intent (SOI).

It is unarguable that there should be accountability for outcomes. The objectives of the public sector are constitutionally determined by an elected government. Government must meet the needs of its electorate and those needs are ultimately served by the achievement of desired policy outcomes. It follows that accountability for outcomes should ultimately rest with the ministers who have contracted for the delivery of outputs which contribute to those outcomes.

An important component of this debate is a clear understanding of accountability. The public sector in New Zealand has equated accountability with answerability (Gregory, 1998, p.529; Boston et al., 1996, p.320). Answerability is in the same spirit as Gray, Owen and Adams' definition of accountability as 'the duty to provide an account (by no means necessarily a financial account) or reckoning of those actions for which one is held responsible' (Gray, Owen and Adams, 1996, p.38).

Gregory and Hicks (1999) have subsequently argued that accountability in the sense of answerability is a narrow application of accountability and that this application may cause damage in the long term to public institutions, albeit while succeeding in delivering enhanced shorter-term accountability. They have argued for recognition of responsible accountability, which incorporates 'a willingness to answer honestly for standards of personal behaviour that enhance the real and apparent trustworthiness of public service' (p.8, italics in original). Arguably, emphasis on a contracting environment undermines this sense of accountability from the public service.

Under the doctrine of ministerial responsibility, ministers will be accountable for the actions of their departments (Pallot, 1998). Indeed, the public in New Zealand has continued to hold the political executive to account irrespective of subtleties within legislation. However, this does not absolve chief executives from providing accountability. Scott (2001) acknowledged that the doctrine as proposed by Palmer and Palmer (1997) has changed somewhat in practice:

Chief executives are now much more accountable for the delivery by their departments of specific services, and they can face severance or nonrenewal of contract on performance grounds alone. This is very different from the past, where performance was neither specified nor measured, tenure was permanent and only gross and obvious failure was punished. (Scott, 2001, p.126)

MFO has led to at least one important unintended consequence: it has increased the accountability required by contracting departments and thereby at least by implication shifted accountability away from ministers. Public perceptions of failure to deliver may then result in blame resting with departmental chief executives, who are employed on fixed-term contracts. Thus, chief executives can become the sacrificial lambs, and the risks they now face are exacerbated by the increased accountability which MFO demands of them.

This article first provides background on the reforms which have affected public sector accounting and 
accountability, and then discusses the purpose of the 'Roll Out' document in getting departments to report on their contribution towards governmental outcomes. The effects of MFO are examined using Children, Youth and Family Services (CYF) as an example. Finally, the article reflects on the subtle but potentially damaging effects of shifting accountability away from the political executive.

\section{From cash accounting to accountability for outcomes}

The traditional approach to allocating funds to government departments was through appropriations, with monitoring of the subsequent expenditure. This arguably resulted in a culture within government departments of spending up to the budget allocation, and a public perception that the public sector was not required to provide value for money. The type of restructuring carried out in the late 1980s and early 90s has since become known as New Public Management (NPM). NPM was introduced to counter the widespread belief that there was an excessive amount of waste in the 'old' system. As Norman and Gregory (2003, p.35) summarise, 'the aim of these reforms was to focus the attention of public servants on results rather than bureaucratic procedures'.

A key component of the reforms was to change the way that departmental budgets were allocated (Boston et al., 1996). Input allocations fostered the culture of spending up to the budgeted amounts. Replacing the previous input-based allocation was a model which recognised that inputs were provided to deliver outputs, which would result in government's intended outcomes. The definitions of outputs and outcomes are a critical component of public management in New Zealand.

Outputs and outcomes are defined in the Public Finance Act 1989. Outputs are defined as 'goods or services that are supplied by a department, Crown entity, Office of Parliament, or other person or body; and ... include goods or services that a department, Crown entity, Office of Parliament, or other person or body has agreed or contracted to supply on a contingent basis, but that have not been supplied'. An outcome is defined as a 'state or condition of society, the economy, or the environment; and ... includes a change in that state or condition'.
There is thus a clear distinction between outputs and outcomes. It is apparent that outputs are more measurable in nature, while outcomes hold more qualitative characteristics and are more complex in their composition. They are therefore much less amenable to measurement. The services of the police force are commonly used to illustrate the essential differences between outputs and outcomes. Inputs, under the traditional model, were the funds allocated to pay for expenses such as 'officer hours'. An output for the police force is the number of arrests made, while an outcome of the police force may be a safe and law-abiding society. This simple example already begins to hint at the difficulties that arise when attempts are made to measure outcomes. For outcomes, the relationship between cause and effect is also less obvious, particularly as outcomes frequently are affected by several outputs from various sources and by other external factors, over which government agencies may often have little if any control. Outcomes are significant as the expression of government policy and fulfilment of public expectations.

The State Sector Act 1988 introduced contractual arrangements between the government and departmental chief executives. These 'freed' the executives to manage the inputs by removing restrictive detail from their budget allocations, while making them manage their outputs (Baehler, 2003). Chief executives received inputs and were expected to provide outputs, with ministers responsible for outcomes. The emphasis for chief executives and their departments was clearly and deliberately placed on the delivery of outputs.

Outputs are an appropriate level for accountability, as in most cases they can be measured in some manner. Indeed, the nature of a contract for outputs implies a shared understanding of the measures that are to be used. Outputs and, to a much lesser extent, outcomes became the focus of agreements between the ministers and their departments. The New Zealand Police, for example, contracts for a variety of outputs, including policy advice and ministerial servicing, general crime prevention services, specific crime prevention services and maintenance of public order, police primary response management, investigations, case resolution and support to judicial process, and the road safety programme (New Zealand Police, 2006). 
Davis characterised bureaucracy under NPM as 'concerned not with some nebulous public good but with meeting performance indicators set out in an agency agreement' (cited in Norman and Gregory, 2003, p.37). The business model that was used in shaping the reforms placed pivotal importance on performance management and reporting.

\section{Managing for outcomes: a paradox?}

The State Services Commission (SSC) issued Managing for Outcomes in August 2002. The stated objective of Managing for Outcomes - to encourage departments to report on their contribution to governmental outcomes - attempts to shift government departments' focus from outputs to longer-term outcomes.

However, outcomes under the NPM model were not intended to be measurable - at least not in the way that MFO appears to require. Furthermore, MFO attempts to shift accountability from elected ministers to their departments. Paradoxically, the implementation of MFO may be leading to a shorter-term focus for outcomes rather than raising the timeframe for outputs. This is because the timeframe for outcomes is truncated by focusing on quantitative measures, by the difficulties of effectively reporting the complexity inherent in outcomes and in holding chief executives accountable for outputs within their fixed-term contracts.

The SSC carries out its statutory roles of appointing and assessing the performance of public service chief executives, and investigating and reporting on matters relating to the performance of departments and providing guidance on the integrity and conduct of state servants. MFO seeks to improve the performance of the public service by changing the focus within departments from a one-year timeframe, driven by contracts with government and the budgeting process, to a 'longer term, outcome-focused approach to management' (Steering Group Managing for Outcomes Roll-Out 2003/04, 2002, p.1).

A key point is that departmental chief executives are not to be held accountable for achieving outcomes, but for 'managing for outcomes'. This subtle distinction is critical to the implementation of MFO. Although the document states that chief executives were not to be made accountable for achieving outcomes, MFO does not state who, if anyone, should be accountable for the achievement of outcomes. The intention to manage outputs to ensure that they efficiently and effectively contribute to the ultimate achievement of outcomes is laudable. But how realistic is it?

The Managing for Outcomes document outlines the process departments must follow in determining how their outputs contribute to outcomes. The result of the process is the department's SOI (Steering Group Managing for Outcomes Roll-Out 2003/04, 2002, p.6). This relationship, linking a long-term-focused process to a statement of one year's duration, attempts to align short-term goals with longer-term outcomes. But it raises the question: has MFO resulted in a reduction in the scope or timeframe for outcomes?

The definition of outputs provided in the Public Finance Act ensures that they can be reasonably accounted for, while the definition of outcomes leaves them significantly less amenable to accountability. Modell (2005, p.58) states that 'adequate measures of outcomes are pivotal for ascertaining the effectiveness of public-sector organisations'. While Modell supports outcomes as more important than outputs, outcomes are not widely used in accountability regimes. Modell acknowledges that proxy measures of outcomes tend to be closely linked to operating process considerations (p.63), which suggests that reporting is more closely linked with outputs than outcomes.

Modell's assertion that outcomes are pivotal for ascertaining the effectiveness of public sector organisations raises the question: who should be accountable for them? The answer would seem to be that MFO requires greater accountability from the chief executives of the contracted departments.

This situation can be illustrated by reference to the case of Children, Youth and Family Services.

\section{MFO in practice: Child, Youth and Family Services}

CYF was created as a government department in 1999 and had statutory duties under the Children, Young Persons and Their Families Act 1989, including:

(a) advanc[ing] the wellbeing of families and the wellbeing of children and young persons as members of families, whanau, hapu, iwi, and family groups: 
(b) mak [ing] provision for families, whanau, hapu, iwi, and family groups to receive assistance in caring for their children and young persons:

(c) mak [ing] provision for matters relating to children and young persons who are in need of care or protection or who have offended against the law to be resolved, wherever possible, by their own family, whanau, hapu, iwi, or family group. (Children, Young Persons and Their Families Act 1989, preamble)

The department has multiple targets, and analysis of all of its objectives would provide more information than is needed in the present discussion. So CYF's main function, the care and protection of children, will be used to illustrate MFO's results.

The output expense for care and protection services described in CYF's 2006 SOI outlines discrete social work processes and activities as performance measures (see Appendix 1). Such processes and activities are unlikely to be considered a final product or service that is delivered externally as the Public Finance Act's output definition would require. This evidence supports Modell's statement that proxies tend to focus on processes.

'Outcome indicators' are used by CYF and the Ministry of Social Development (MSD) ${ }^{1}$ in their respective SOIs. No reference is made in the Public Finance Act nor in MFO to outcome indicators, but it is apparent that outcome indicators are an intermediate step indicating how each departmental output contributes to eventual outcomes. The necessity for intermediate steps can lead to a shorter-term focus for outcomes.

The outcomes to which CYF contributes under its 2006 SOI are narrower than their previous definition, partly due to a major external review of CYF, which coincided with the introduction of the MFO environment. The focus has narrowed from the previous outcomes, which spoke of 'children and young people [being] respected and valued and [having] a say in decisions that affect them' (CYF, 2005, p.23). Now, they speak of 'the safety and security of children and young people' (MSD, 2006), in line with recommendations from the

1 CYF's SOI was included in MSD's SOI in 2006, as CYF was in the process of being absorbed by the ministry.
Baseline Review. The 2006 SOI (p.120) indicates that as a priority, CYF's outcomes should be focused on preventing the recurrence of harm and child and youth reoffending. CYF openly states in its 2005 SOI that it should not be expected to be a broadly focused family support service or to lead community development.

CYF has attempted to define its outcome indicators in the last two years, but has not yet completed this task. Of the seven outcome statements in its 2006 SOI, only two have final outcome indicators, two are 'works in progress', and for the remaining three CYF is still searching for appropriate indicators (refer to Appendix 2.) It would seem that CYF has adopted its final outcome indicators for their ready measurability, such as the rate of re-substantiation of abuse, and rates of offending and reoffending. These are essentially shortterm measures, indicating that the drive for MFO has resulted in a scaling back of the department's intent and in reporting which focuses on process rather than actual services or activities.

The final outcome indicators do not acknowledge that there are many external factors that have an impact on the effectiveness of CYF's interventions. As in CYF's case, so too in many departments: it is common for many outputs to contribute to the achievement of a single outcome. Although CYF is the lead agency, the very nature of child care and protection work requires co-operation across different agencies, communities and families. The success of this work depends on how well all parties work together (Walker, 2006). There is no attempt in the outcome indicators to reflect the need for this co-operation.

This situation can only enhance the pressures on departmental chief executives. Usually, they are initially appointed for a five-year term, under the terms of the State Sector Act 1988, s.38(1). Thus, because the pressure is on chief executives to produce results within a relatively short timeframe, they have a strong incentive to put in place processes that will achieve this end, and little encouragement to fully and genuinely consider longer-term results.

CYF has had difficulty in retaining its chief executives, having had four within the past seven years. In light of the pressures the agency is under, always with inadequate resourcing, and in a context of high political 
risk and predominantly negative publicity (little public recognition is given to the effective and successful work it does), this may not be surprising.

\section{Conclusion}

MFO brings about a subtle but very significant shift in accountability for outcomes, transferring the burden, on the face of it at least, from the political executive to the departments responsible for delivering outputs. Ultimately, accountability for policy outcomes should continue to rest with ministers, and in practice the public in New Zealand can still be expected to be strongly critical of ministers when things go wrong. People generally know little of or care less about distinctions between outputs and outcomes.

It is ironic that MFO is reinforcing an emphasis on bureaucratic procedures when it is intended to more strongly focus departmental attention on the collaborative achievement of outcomes. This cannot be readily measured in many cases and attempts to enhance accountability by trying to do so are likely to succeed at the cost of oversimplifying governance and governmental complexities.

The solution, if there is one, is not to try to make longerterm outcomes rigorously measurable, as if they were shorter-term outputs. It should instead involve a search for smarter, and more politically contestable, ways of ensuring accountability, ways that recognise the complex and often necessarily ambiguous nature of many policy outcomes, as they become apparent over time.

\section{Appendix 1: Non-financial performance indicators from MSD's Statement of Intent 2006/07}

\section{Output Expense: Care and Protection Services}

\section{Description}

This output expense includes the provision of services, both statutory and informal, that protect and assist children and young people who are in need of care and protection.

\section{Scope}

The scope of this output expense includes:

- the notification, investigation, and assessment of reports about children and young people at risk of physical, sexual, or emotional abuse, neglect, selfharm, or behavioural difficulties

- the management of casework where Child, Youth and Family intervenes to achieve care and protection outcomes

- the coordination of Care and Protection Family Group Conferences

- support for families to improve their capacity to meet their care, control, and support responsibilities

- the provision of care in the nature of foster care and residential services

\section{Performance Information}

\begin{tabular}{|l|l|l|l|}
\hline $\begin{array}{l}\text { 2004/2005 } \\
\text { Result }\end{array}$ & Performance measures & \multicolumn{1}{|c|}{$\begin{array}{l}\text { Standard } \\
\mathbf{2 0 0 5 / 2 0 0 6}\end{array}$} & $\begin{array}{l}\text { Standard } \\
\mathbf{2 0 0 6 / 2 0 0 7}\end{array}$ \\
\hline 53,097 & $\begin{array}{l}\text { Quantity } \\
\text { Number of intake notifications received by Child, Youth } \\
\text { and Family: }\end{array}$ & $51,500-59,700$ & $\mathbf{7 1 , 4 0 0 - 7 8 , 9 1 0}$ \\
\hline 43,460 & $\begin{array}{l}\text { Number of intake notifications that require further action } \\
\text { (FARs): }\end{array}$ & $42,900-49,850$ & $52,300-57,800$ \\
\hline 5,422 & $\begin{array}{l}\text { Number of care and protection Family Group } \\
\text { Conferences: }\end{array}$ & $\begin{array}{l}\text { Number of children and young people in care and } \\
\text { protection care placements at any time during the year } \\
\text { (as measured at the end of each month): }\end{array}$ & $\mathbf{5 , 1 5 0 - 6 , 0 0 0}$ \\
\hline
\end{tabular}




\begin{tabular}{|c|c|c|c|}
\hline & $\begin{array}{l}\text { Timeliness } \\
\text { Response to notifications } \\
\text { Notifications allocated to a social worker for investigation } \\
\text { within timeframes: }\end{array}$ & & \\
\hline $97.8 \%$ & Critical - within 24 hours & $95 \%-100 \%$ & $95 \%-100 \%$ \\
\hline \multirow[t]{2}{*}{$95.9 \%$} & Very Urgent - within 48 hours & $95 \%-100 \%$ & $90 \%-95 \%$ \\
\hline & $\begin{array}{l}\text { Action taken at sites by a social worker to establish the } \\
\text { immediate safety of the child or young person, and to } \\
\text { confirm the response time and further action required, } \\
\text { within timeframes: }\end{array}$ & & \\
\hline $51 \%$ & Urgent - within 7 days & $50 \%-85 \%$ & $50 \%-85 \% 47$ \\
\hline $62.4 \%$ & Low Urgent - within 28 days & $50 \%-85 \%$ & $50 \%-85 \%$ \\
\hline $58.7 \%$ & Investigations will be completed in a timely manner & $\begin{array}{l}70 \% \text { in } 90 \text { days } \\
\text { if FAR received } \\
\text { is less than } \\
48,050.70 \% \\
\text { in } 120 \text { days if } \\
\text { FAR is } 48,050 \\
\text { or more }\end{array}$ & $\begin{array}{l}70 \% \text { in } 90 \\
\text { days }\end{array}$ \\
\hline
\end{tabular}

- the provision of resolution services to assist achieving care and protection needs

- the improvement of life outcomes of the children, young people and families involved.

This output expense also includes the provision of services to support other statutory responsibilities of the Chief Executive such as reports provided to the Family Court under the Care of Children Act 2004.

\section{References}

Baehler, K. (2003) “"Managing for Outcomes”: accountability and thrust', Australian Journal of Public Administration, December, pp.23-34

Boston, J., J. Martin, J. Pallot and P. Walsh (1996) Public Management: the New Zealand model, Auckland: Oxford University Press

'CYF left in the lurch', New Zealand Herald, 10 December 2005

Children, Youth and Families (2005) Statement of Intent 2005

Gray, R., D. Owen and C. Adams (1996) Accounting \& Accountability: changes and challenges in Corporate
Social and Environmental Reporting, London, New York: Prentice Hall

Gregory, R. (1998) 'Political responsibility for bureaucratic incompetence: tragedy at Cave Creek', Public Administration, 76, autumn, pp.519-38

Gregory, R. and C. Hicks (1999) 'Promoting public service integrity: a case for responsible accountability', Australian Journal of Public Administration, 58(4), December, pp.3-15

Haines, L. (2003) 'CYFS boss quits after "really painful" report', Dominion Post, 3 November, p.A1

Ministry of Social Development (2006) Statement of Intent 2006

Modell, S. (2005) 'Performance management in the public sector: past experience, current practices and future challenges', Australian Accounting Review, November, pp.56-66

New Zealand Government (1989) Children, Young Persons and Their Families Act

New Zealand Police (2006) Annual Report

Norman, R. and R. Gregory (2003) 'Paradoxes and pendulum swings: performance management in New 


\section{Appendix 2: Outcome Indicators for CYF from MSD's Statement of Intent 2006/07}

\section{Outcome Indicators}

\begin{tabular}{|c|c|c|}
\hline $\begin{array}{l}\text { FREE FROM ABUSE AND } \\
\text { NEGLECT }\end{array}$ & $\begin{array}{l}\text { FINAL OUTCOME } \\
\text { INDICATOR }\end{array}$ & $\begin{array}{l}\text { PROPOSED OUTCOME } \\
\text { INDICATOR }\end{array}$ \\
\hline $\begin{array}{l}\text { To prevent the recurrence of child } \\
\text { abuse, neglect and insecurity of } \\
\text { care }\end{array}$ & $\begin{array}{l}\text { Re-substantiation of abuse, } \\
\text { neglect or insecurity of care. }\end{array}$ & \\
\hline $\begin{array}{l}\text { That the effects of harm are } \\
\text { addressed }\end{array}$ & & $\begin{array}{l}\text { An appropriate indicator is being } \\
\text { investigated. } \\
\text { Our review of last year's indicator } \\
\text { "FGC plans/FWAs/Court Orders } \\
\text { completed and objectives met" has } \\
\text { found that while we capture data } \\
\text { on this indicator, it does not } \\
\text { appropriately measure progress } \\
\text { towards this outcome. } \\
\text { An appropriate indicator is being } \\
\text { investigated. }\end{array}$ \\
\hline $\begin{array}{l}\text { To prevent the first occurrence of } \\
\text { abuse, neglect or insecurity of care }\end{array}$ & & $\begin{array}{l}\text { Our review of last year's indicator } \\
\text { "Percentage of cases that are referred } \\
\text { to a third party organisation (prior to } \\
\text { investigation) that are not re-notified" } \\
\text { has found that while we capture } \\
\text { this data, the indicator itself does } \\
\text { not appropriately measure progress } \\
\text { towards this outcome. }\end{array}$ \\
\hline \multirow[t]{2}{*}{$\begin{array}{l}\text { To restore or improve wellbeing } \\
\text { (including achieving permanency } \\
\text { and stability) }\end{array}$} & & $\begin{array}{l}\text { Improvement in developmental } \\
\text { milestones (including for children in } \\
\text { care) along educational attainment, } \\
\text { behaviour and health dimensions. }\end{array}$ \\
\hline & & $\begin{array}{l}\text { Proportion (\%) of children in care } \\
\text { placed with their family or whanau. } \\
\text { Proportion (\%) of cases in which } \\
\text { the objectives of permanency plans } \\
\text { are met. }\end{array}$ \\
\hline
\end{tabular}

Zealand's public sector', Australian Journal of Public Administration, December, pp.35-49

Pallot, J. (1998) 'New Public Management reform in New Zealand: the collective strategy phase', International Public Management Journal, 1 (1), pp.1-18
Palmer, G. and M. Palmer (1997) Bridled Power: New Zealand government under MMP, Auckland: Oxford University Press

Ryan, B. (2006) 'Managing for outcomes: understanding clients, Policy Quarterly, 2 (4), pp.39-46 


\begin{tabular}{|l|l|l|}
$\begin{array}{l}\text { CHILDREN AND YOUNG } \\
\text { PEOPLE FREE FROM } \\
\text { OFFENDING }\end{array}$ & $\begin{array}{l}\text { FINAL OUTCOME } \\
\text { INDICATOR }\end{array}$ & $\begin{array}{l}\text { PROPOSED OUTCOME } \\
\text { INDICATOR }\end{array}$ \\
\hline $\begin{array}{l}\text { To reduce the rate and severity of } \\
\text { child and youth offending }\end{array}$ & $\begin{array}{l}\text { Rate of offending } \\
\text { Rate of re-offending } \\
\text { Severity of re-offending }\end{array}$ & $\begin{array}{l}\text { Victim perception of whether the } \\
\text { offender has been held to account } \\
\text { for their offending following the } \\
\text { Family Group Conference (FGC) } \\
\text { for offending }\end{array}$ \\
\hline $\begin{array}{l}\text { Offender perception of whether } \\
\text { they have been held to account for } \\
\text { their offending following the FGC }\end{array}$ \\
\hline To restore or improve wellbeing & $\begin{array}{l}\text { An appropriate indicator is being } \\
\text { investigated. }\end{array}$ \\
\hline $\begin{array}{l}\text { Our review of last year's proposed } \\
\text { indicator “The objectives of the } \\
\text { Youth Justice FGC or Court Order } \\
\text { have been met" has found that this } \\
\text { indicator does not appropriately } \\
\text { measure progress towards this } \\
\text { outcome. }\end{array}$ \\
\hline
\end{tabular}

Scott, G. (2001) Public Management in New Zealand: lessons and challenges, Wellington: New Zealand Business Roundtable

Steering Group Managing for Outcomes Roll-out 2003/04 (2002) Managing for outcomes: guidance for departments, Wellington: State Services Commission

Walker, A. (2006) 'Child protection and interagency collaboration', Policy Quarterly, 2 (4), pp.29-37
Karen Lewis is a lecturer in the College of Business and Economics at the University of Canterbury. She teaches financial accounting, and has an interest in public sector accounting and accounting history. Her current research focuses on the relative merits of sector-neutral accounting in $\mathrm{New}$ Zealand. She can be contacted at: Karen.Lewis@canterbury.ac.nz 